\title{
The Effect of Peer Assessment on the Evaluation Process of Students
}

\author{
Jawaher Mohammed Alzaid ${ }^{1}$ \\ ${ }^{1}$ Department of Psychology, College of Education, King Saud University, Saudi Arabia \\ Correspondence: Jawaher Mohammed Alzaid, Psychology Department, Measurment and Evaluation Section, \\ College of Education, King Saud University, Prince Turkey street, Exit 2, Riyadh, Saudi Arabia. E-mail: \\ prof.jawaheralzed@gmail.com
}

$\begin{array}{cc}\text { Received: January 17, } 2017 & \text { Accepted: February 27, } 2017 \quad \text { Online Published: May 29, } 2017 \\ \text { doi:10.5539/ies.v10n6p159 } & \text { URL: https://doi.org/10.5539/ies.v10n6p159 }\end{array}$

\begin{abstract}
This study aims at finding out the effect of peer assessment on the evaluation process of students. The hypothesis underlying this study is that assessment is an integral part of the learning process, which should play an important role in the educational model. The current study will emphasize the importance of using peer assessment as a tool to engage students in the evaluation process, clarify the role of peer assessment in promoting student learning, diversify the scope of the evaluation through the frameworks of theory and methodology to get to understand the uses and limitations of peer assessment as a tool for assessment, and discuss the goals and benefits that can be achieved by the students from practicing peer assessment in accordance with scientific standards and bases, which emphasize active participation of the students in their learning and responsibility. Additionally, this study will check the credibility of peer assessments as a suitable tool in the assessment process. Findings show that there is a statistically significant relationship between the assessment of peers to each other, as well as between peer assessment and teacher assessment.
\end{abstract}

Keywords: peer assessment, evaluation process, assessment tool, credibility of peer review

This is a research project that was supported by a grant from the Research Center for the Humanities, Deanship of Scientific Research at King Saud University.

\section{Introduction}

Focus on learning and learners are now a central theme in the educational policies and practices. While there are still huge needs for achieving higher grades as measured in accordance with the evaluation criteria, benefiting of students from their own learning, and involving them in assessing their own learning and the ability to make a decision (Deakin-Crick et al., 2005). Peer assessment is an important element of designing learning environments in order for them to become more participatory among students, which can achieve concepts such as learning between peers, collaborative learning, and problem-solving based learning (Kollar \& Fisher, 2010; Tan \& Keat, 2005).

Peer assessment in the education field has been achieved at an increasing rate in recent decades, using it as an assessment tool (Gielen et al., 2011). It represents a system for learning built on the basis of that learning directed around the learner with the other in depending on effective learning, which focuses on the full integration of the student in the process of collaborative learning with peers under the supervision of the teacher (Thomas et al., 2011). Peer assessment is used to enhance learning as an effective way to increase motivation for students by engaging them in the evaluation process which has received attention in recent years from a number of international universities (Rimer, 2007), and to encourage peers to help each other to master the topic of learning.

Peer assessment also aims to describe the assessment processes that foster future learning and mitigate difficulties that are expected to occur. It also aims to transform students from mere receivers of knowledge from teachers to memorize and recall on tests to active learners and participants in learning and evaluation process, interact, search and explore, and reach to relationships between objects in order to generate new knowledge characterized by critical thinking and creativity. Peer assessment also helps to ensure a quality education for all 
students (Rogers \& Threatt, 2000) and develop learner's self-direction as one of the quality measures in education (Papinczak et al., 2005).

Sluijsmans et al. (1998) anticipated that the design of the curriculum should also be linked to designing assessment mechanisms. Curriculum designers should integrate assessment forms, such as peer-to-peer assessment, in order to be a part of the student-centered change process. This change requires a transformation of focus from summative assessment to formative one, and from external to internal assessment, and also from assessing products to assessing the process as well.

Assessment procedures provided to students to assess their competencies by teachers test their content knowledge instead of focusing on areas such as problem solving communication and critical thinking skills, teamwork, and respect others. These competencies are not assessed easily by the traditional forms of content-based measurements of knowledge (Lew et al., 2008). Thus, problem-solving based peer and learning assessments have received an increasing attention in the field of education. The European Commission of Higher Education emphasized the importance of focusing on peer assessment skills as a new perspective where student assessment shifts from traditional testing to giving students an active role in the learning and assessment processes (Lladó et al., 2014).

The evolving needs of the global labor market have promoted the need to train students to take responsibility for their learning and personal and professional continuous development. Problem-solving based learning recommended problem-based learning as an effective methodology for giving the students this responsibility (Kollar \& Fisher, 2010; Wesson, 2014; Spiller, 2009). One of the objectives of this study is to investigate the role of peer assessment in learning, considering assessment as an integral part of the learning process, and reaching to an understanding of the uses and limits of peer assessment as an assessment tool for learning outcomes, which emphasizes active participation of students in their learning, responsibility of the learner, measurement of skills of metacognition, and applying a collaborative model of dialogue for education and learning.

\section{Review of Literature}

Savin-Baden (2004) claims that assessment is one of the most controversial topics in problem-based learning. Students often learn through interaction with the group, and they are often not rewarded in classrooms in spite of the effort and time they spend on their work, and therefore that do not translate into academic degrees (Tan \& Keat, 2005). It may be understood what has been written about peer assessment as a tool for measurement and evaluation in problem-based learning, that it falls into three categories when used as a tool in terms of learning, promotion, and authority. The common factor of these three areas is that there is a degree of student participation, and this participation takes different forms and levels (Tan \& Keat, 2005).

Peer assessment is the tool with which students evaluate the quality or quantity of their peers' performance, and that stimulates students to reflect, discuss and collaborate (Strijbos \& Sluijsmans, 2010).It requires students to make notes or scores or both about their peers' product or performance based on standards of excellence for them. Students also participate in a determining those standards (Boud \& Falchikov, 2007).

Spiller (2009) claims that peer assessment is a mutual process between students. The participation of students in commenting on the work of others increases their capacity for making intellectual choices and judgments, as well as the students receiving feedback from their peers helps them acquire a wide range of ideas about their work to promote and achieve development and improvement in their learning. Students' learning opportunities are less when they become passive recipients of assessments results. The future of learning requires the involvement of students in the learning and evaluation process, which reflects to improving results, both short and long-term, as well as learning in the future. (Thomas et al., 2011)

Landry et al. (2014) stress that there is a significant improvement in the performance of students after doing peer assessment on a cumulative basis, where the results showed the importance of using peer assessment as a tool for student-based learning, and that more than $90 \%$ of students either agreed or strongly agreed that peer assessment was a valuable learning experience.

Lladó et al. (2014) claim that students have a positive attitude toward peer-assessment methodology before and after its application. It stimulates student performance and facilitates the acquisition of learning at different levels. Lew et al. (2008) also noted in an exploratory study that students agree that peer assessment enables them to aid in the learning of their peers, that it was a fair way to evaluate them, and doesn't let personal relationships with peers influence their evaluations. Additionally, students perceive the process of peer assessment as a learning experience important to the evaluation process. Another study examined the connection between marks of students in higher education who have been evaluated for sustainable development with marks of peer 
assessments as a way to measure the sincerity of peer assessment in the evaluation process. The results indicate that students, even those who did not have previous experience in assessing peers, were able to evaluate the work of their peers and make their judgments reasonably accurate in peer assessments (Kearney et al., 2015).

Falchikov and Goldfinch (2000) conducted a meta-analysis study of 48 studies aimed to compare peer assessment to teacher assessment. The results showed that many of these studies have confirmed the existence of some similarities between peer and teacher assessments. Sahin (2008) also claims that peer assessment is one of the alternative assessment methods, which trained students in higher education to use peer assessment as a tool of evaluation and compared it to teacher assessment. The results of the study revealed that peer assessment proved to be similar to teacher assessment, which can be considered as a recognized method and used effectively by teachers.

\subsection{Honesty and Credibility of Peer Assessment}

Honesty and credibility are measures of consistency of peer assessment, and the higher the consistency the less is diversity. Therefore, the task of improving peer assessment systems does not have a high level of honestly when grades are the only objective at the expense of other factors such as different reactions to a certain task, which needs investigating on how to improve students' perceptions about peer review criteria, and refrain from individual ratings that could lead to questioning the credibility of this assessment (Cho et al., 2006). Many studies confirm that the issues of honesty and credibility are the most difficult in student assessment (Elander, 2004; Rust et al., 2003), which requires formulation of evaluation criteria to reduce bias and errors in grading (Elander, 2004).

Among the many criticisms directed at peer assessment is the difficulty of achieving acceptable levels of honest and reliable assessment results, which requires peer assessment to be seen as a means to improve the learning process rather than a goal in itself. A study done by Marsh et al., (2008) confirmed the importance of establishing common standards to include populations from different backgrounds, as well as relevant external standards to confirm the genuineness of peer assessment results and test potential biasness by populations. Chang (2011) presented some effective methods that help promote the credibility of peer assessment results such as deep understanding of the purpose of evaluation, and the use promotion and diversity methods in the levels of the participants in evaluation. The difficulty of reaching to an agreement among populations may lead to poor peer assessment results, which requires a certain number of people to achieve a more acceptable credibility (Marsh et al., 2008).

Race (2001) argues that peers should be chosen at random because they are less likely to be biased, and can achieve more honest results. He also feels that the work between peers is more effective when each element of the work is evaluated in accordance with the evaluation criteria in order to achieve a high level of consistency. Cho \& MacArthur (2010) confirm that those who receive feedback from peers improve their performance more than students who receive feedback from one peer, and this achieves a high level of reliability that requires a degree of agreement and consistency between the various assessments of peers per student, which represents a variable very important to increase the level of confidence in evaluation results (Elander, 2004).

\subsection{Goals and Benefits of Peer Assessment}

Tan and Keat (2005) study proved that there are many variables in peer assessment, and even if they mainly involve students to provide feedback to other students, there are still some reactions from peers containing some difficulties; this is widely recognized. Spiller (2009); Kollar \& Fisher (2010) proved that students often have concerns about the evaluation processes, so it is not surprising that there is some hesitations or fears about showing their work to others, so they think that their peers are not qualified to assess their work, and that only teachers are assigned to the evaluation process. These concerns are diminished when the peer assessment activity is formative rather than summative, but there is ample evidence that peer assessment can be used reliably for summative work (Gielen \& Wever, 2015; Lladó et al., 2014; University of Sussex US, 2015). However, this requires explanation of the purposes and advantages of peer assessment and feedback activity at the beginning.

Some studies argue that there is a concern that students may provide exaggerated perceptions, excessive, or underestimated perceptions in estimating the achievements of their peers. These concerns, from the perspective of measurement, indicate the increase in contrast ratio, which threatens the credibility of grades (Ross, 2006.). In an attempt to ensure a suitable environment for peer learning, Spiller (2009) argues that the introduction of grading in peer assessment might create another set of complex issues, such as if peers decide to give their peers the grades they deserved. These grades must be only one of a number of different grades awarded for a specific task or process. As the investigation into the implications of peer assessment on personal variables such as psychological health, interdependence, trust, and narcissism, and the effects of different types of feedback that 
have some negative effects, need to be turned to have a positive impact on learning (Kollar \& Fisher, 2010). That can be possible by formulating evaluation criteria to reduce bias and mistakes in grading (Elander, 2004).

Lutze-Mann (2015) and Ross (2006) presented a number of benefits for using peer assessment as a tool of assessment to evaluate learning:

1) Peer assessment provides consistent results across the evaluation criteria and tasks in short period of time.

2) Peer assessment gives information about student achievement that corresponds in part with the information resulting from the evaluation of teachers, as it leads to higher student achievement.

3) Peer assessment contributes in enhancing strengths through training students on how to evaluate their work.

4) It involves students in the learning process and developing their ability to think critically.

5) 5. Learning from of critical evaluation and feedback from others.

6) Developing social skills such as cooperative learning.

Spiller (2009) adds that participation of peers in assessment provides students with certain characteristics, including a number of features, such as:

- Promoting education.

- Promoting students' responsibility for their actions.

- Providing students with the skills to apply standards and criteria.

- Providing an amount of modeling.

- Involving students in judging their performance and their peers', which increases evaluation experience and benefiting from feedback.

- Decreasing depending on teachers and increasing independence in the evaluation process.

\subsection{The Students' and Teachers' Roles in Preparing Peer Assessment Forms}

Peer assessment as an assessment tool is more reflective of student performance, because group members spend a significant time in working with each other, and are, thus, in a good position to recognize and assess the efforts and contributions of their peers (Ghorpade \& Lackritz, 2001). In a study conducted by Lladó et al. (2014) in a survey of students' views about their role and the role of teachers in the development of evaluation criteria, the students confirmed that they are more familiar with what is going on exactly when they perform peer assessment, which helps make work easier and makes the evaluation more convincing. The study also confirmed that there should be additional contribution from teachers to the evaluation criteria so students are able to interact and follow-up.

Lew et al. (2008) also confirmed in a survey on students' views about the use of peer assessment that it had helped in their learning, and that the process of peer assessment was a valuable learning experience done in an unbiased manner and tends to not involve personal relationships when considering the process of peer assessment. A study done by Sivan (2002) indicated in a survey of students who have applied peer assessment that they found it a suitable method for their learning, and it is seen as a good mechanism to develop critical thinking and learning from the work of others, and that it provides an opportunity to take responsibility and learn how to make decisions. The students also indicated that the use of peer assessment stimulates cooperation.

Thomas et al. (2011) confirmed that teachers should participate with their students in the assessment process and abandon their authority, and that there should be an exchange of authority and lead students to assess themselves. In order to activate the role of students in preparation of standards that will be the basis on which peer assessments are performed, it requires to debate about standards that help students to think about the activity to be evaluated, and present a feedback about the activities of peer assessment, by giving students opportunities in a number of aspects. (University of Sussex, USA, 2015):

- Applying of standards: assessment of someone else's work means understanding and applying classification standards, and that occurs the process of peer assessment to get a better understanding of the level expected of them by providing more peers to become more capable of assessing their own work.

- Learning from examples: seeing the examples of how to address other people for an assessment task or model samples and employ them to organize the work.

- Receiving Feedback: Feedback that the students give each other is likely to be different from teacher feedback. Students are likely to write their feedback in a different way and may have a clearer 
understanding of what is really useful at that stage of the process, despite the fact that both should be related to the criteria.

Spiller (2009) argues that students become more able to gain confidence in peer assessment with practice and become more efficient when exchanging and discussing observations. Liua and Lib's (2014) study emphasize the importance of training on the skills of peer assessment before engaging in assessment activities and students reviewing learning concepts, and compare their assessments with teacher evaluation. The study concluded that training on in peer assessment leads to a decrease in contradictions between students' grading and the teacher's grading, providing the highest quality of observations of peers through peer assessment.

\section{Method}

\subsection{Methodology}

This study follows an evidentiary comparative method to prove the following hypotheses:

1) There are statistical significant differences between peer assessment among the organizational and academic skills.

2) There are no statistical significant differences between peer assessment and teacher assessment in each of the organizational and academic skills.

3) There is a statistical significant relationship between peer assessment and teacher assessment.

\subsection{Sample}

A purposive sample was chosen from the students of the Department of Psychology at King Saud University. It consists of 50 students during the second semester of the academic year 2015-2016.

\subsection{Tools}

\subsubsection{Peer Assessment Template}

To prepare a template for peer assessment, the researcher reviewed and analyzed theoretical literature and studies related to learning assessment to get to the appropriate form (Wesson, 2014; Kollar \& Fisher, 2010). The first image was prepared to include two dimensions peer assessments: the first dimension includes organizational skills and consists of 5 tasks, and the second dimension includes academic skills and consists of 6 tasks.

\subsubsection{Validity and Reliability}

\section{A-External Validity}

The researcher checked the reliability of peer assessment template by showing it to 6 evaluators from faculty members in the Faculty of Education at King Saud University. After they have been provided with goals and aspects of the assessment, some modifications were made according to the evaluators' suggestions. The ratio of validity was more than $80 \%$.

\section{B-Internal Validity}

The validity of each task of the peer assessment template was measured in each dimension. The measurement of the validity of dimensions was done through the application of the model template on a sample survey consisting of 33 student of the Department of Psychology, and thus Pearson's correlation coefficient was found. Table 1 presents the overall Pearson Correlation of each dimension task. 
Table 1. The overall Pearson correlation of each dimension task

\begin{tabular}{cccc}
\hline $\begin{array}{c}\text { Correlation } \\
\text { Coefficient }\end{array}$ & Academic Skills Tasks & $\begin{array}{c}\text { Correlation } \\
\text { Coefficient }\end{array}$ & $\begin{array}{c}\text { Organizational skills } \\
\text { Tasks }\end{array}$ \\
\hline $.886^{* *}$ & Descriptive Statistics & $.737^{* *}$ & Leadership \\
$.805^{* *}$ & Statistical Hypothesis & $.587^{* *}$ & Listening \\
$.619^{* *}$ & Interpretation of Statistical & $.786^{* *}$ & Feedback \\
$.805^{* *}$ & Significance & $.732^{* *}$ & Cooperation \\
$.868^{* *}$ & Parametric Statistical methods & $.697^{* *}$ & Time Management \\
& non-Parametric Statistical & & \\
$.868^{* *}$ & methods & & \\
\hline
\end{tabular}

**Statically significant at $\alpha=0.01$.

Table 1 shows that the overall correlation value of tasks of the organizational skills dimension has ranged between $(0.587-0.786)$, and the overall correlation value of tasks of the academic skills dimension has ranged between $(0.619-0.886)$, and all those correlations are statistically significant $(\mathrm{P}<0.01)$ which indicates that the tasks are consistent in the measurement of the dimensions of the peer assessment template model.

\section{C-Reliability}

To find out the reliability of peer assessment template model, the internal consistency was measured using Cronbach's Alpha among the average peer assessment grade on each task of the assessment template tasks and the overall score for each dimension on a sample survey consisting of 33 students from the Department of Psychology.

Table 2. Consistency in Cronbach's Alpha

\begin{tabular}{cc}
$\begin{array}{c}\text { Cronbach's Alpha } \\
\text { Coefficient }\end{array}$ & Standard \\
\hline .745 & Organizational Skills Dimension \\
.876 & Academic skills Dimension \\
.865 & Total score \\
\hline
\end{tabular}

Table 2 shows that Cronbach's Alpha coefficients have ranged between 0.745 and 0.876 , which indicates that the peer assessment template model is suitably reliable.

\subsubsection{Steps to Apply the Peer Assessment Template (Appendix)}

Students were provided with the principles and guidelines when assessing peers according to the criteria defined in the peer assessment form during the activity. The model was applied according to the following steps:

1) The first activity in the peer assessment starts with performing a task, where working groups of female students A, B, C, D were formed to perform a certain task such as a solution to a statistical problem in one subject of statistical psychology course, or applying one of the themes provided by using the SPSS program, and any other tasks related to the requirements of the course. The performance of professional students' tasks who work on the same task are compared and observed during the performance of tasks that lead to the desired learning.

2) The second activity in peer assessment is to provide feedback. Each student discusses both her performance and her colleagues' in the group according to the criteria defined in the peer assessment form. The focus here is not only on the evaluation of the final product but also the process that reached to that result, while discussing the weaknesses in the performance of each student's task in an interactive manner between the peers.

3) The third activity in peer assessment is to receive feedback, where student A listens or reads the comments and evaluations of peers in the group about the performance of the tasks while giving opportunities to communicate about these observations. That is confirmed by some experimental studies that assess the positive impact on the success of peer assessment, which reflects on the cognitive level of the student.

4) The final activity in peer assessment is revision of tasks for each group of students according to the peer 
assessment form based on the evaluations and the comments of peers to improve the performance of the tasks.

Thus the application of the strategy of peer assessment for all students in each group is done in accordance with the peer assessment form interchangeably to reach a final assessment and measure the average rating for each student on each of the peer assessment form skills.

This model allows for the grading systems ranging from 4 for very high to 1 for low, and therefore this model is an example of a final report, but it is also a tool to provide formative assessment feedback about what learners need to work on to progress learning.

\subsubsection{How to Take Advantage of the Peer Assessment Form}

Peer assessment may be a new concept for students, so academics need to take into account some considerations (Wesson, 2014), which consist of:

- $\quad$ Talking with the students as a group for they may not be familiar with the practice, expectations, and goals of peer assessment.

- $\quad$ Establishing of peer groups and the culture of working with peers early on before performing a task.

- $\quad$ Involving each student within the group in appropriate educational events.

- Helping students to access a list of items to assess the type of participation, and defining the evaluation criteria of the task with students, and providing the necessary tools.

- $\quad$ Clarifying examples of good practices and feedback of peer review, whether positive or negative.

- $\quad$ Organizing learning, providing incentives and recognition of progress made by students.

- $\quad$ Preparing a model of the task that includes adjustable criteria and methodology of assessment in light of educational task inputs.

\section{Results and Discussion}

This portion of the study is dedicated to present the results of the study.

Hypothesis\#1: There are statistical significant differences between peer assessment among the organizational and academic skills.

To check this hypothesis, Kendall rank correlation coefficient was found among the skills of each dimension of the assessment model to verify the degree of concordance between peers in their assessment of skills. Table 3 presents the results of Kendall correlation matrix among peer assessment of organizational skills.

Table 3. Kendall correlation matrix among peer assessment of organizational skills

\begin{tabular}{|c|c|c|c|c|c|c|}
\hline $\begin{array}{l}\text { Total } \\
\text { Score }\end{array}$ & Time Management & Cooperation & Feedback & Listening & Leadership & Organizational Skills \\
\hline $.589^{* *}$ & $.202^{*}$ & $.467^{* *}$ & $.288^{* *}$ & .127 & 1.000 & Leadership \\
\hline $.305^{* *}$ & -.042 & $.182^{*}$ & $.174^{*}$ & 1.000 & & Listening \\
\hline $.580^{* *}$ & $.248^{* *}$ & $.278^{* *}$ & 1.000 & & & Feedback \\
\hline $.578^{* *}$ & $.197^{*}$ & 1.000 & & & & Cooperation \\
\hline $.409^{* *}$ & 1.000 & & & & & Time Management \\
\hline 1.000 & ${ }^{* *}$ & & & & & Total Score \\
\hline
\end{tabular}

**Statically significant at $\alpha=0.01$.

*Statically significant at $\alpha=0.05$.

Table 3 illustrates the relationship between organizational skills in the peer assessment model, where it shows statistically significant relationships between leadership, feedback, and cooperation at $(\alpha=0.01)$; leadership and time management at $(\alpha=0.05)$; and between listening, feedback, cooperation was statistically significant at $(\alpha=0.05)$, as well as between feedback, cooperation, and time management was a statistically significant at $(\alpha=0.01)$, and between cooperation and time management was a statistically significant at $(\alpha=0.05)$. As well as a clear indication that the relationship between all the tasks with the total score at $(\alpha=0.01)$, while no statically significant relationship appeared between leadership and listening, as well as listening and time management, which shows a poor concordance between the members of the sample on those skills in peer assessment. However Table 4 presents the results of Kendall correlation matrix among peer assessment of the academic 
skills.

Table 4. Kendall correlation matrix among peer assessment of academic skills

\begin{tabular}{|c|c|c|c|c|c|c|c|}
\hline $\begin{array}{l}\text { Total } \\
\text { Score }\end{array}$ & $\begin{array}{c}\text { Use of } \\
\text { Statistical } \\
\text { Package of } \\
\text { SPSS } \\
\end{array}$ & $\begin{array}{c}\text { Non-Parametric } \\
\text { Statistical } \\
\text { methods }\end{array}$ & $\begin{array}{c}\text { Parametric } \\
\text { Statistical } \\
\text { Methods }\end{array}$ & $\begin{array}{l}\text { Interpretation } \\
\text { of Statistical } \\
\text { Significance }\end{array}$ & $\begin{array}{c}\text { Statistical } \\
\text { Hypotheses }\end{array}$ & $\begin{array}{c}\text { Descriptive } \\
\text { Statistics }\end{array}$ & $\begin{array}{c}\text { Academic Skills } \\
\text { Tasks }\end{array}$ \\
\hline $.652^{* *}$ & $.446^{* *}$ & $.605^{* *}$ & $.343^{* *}$ & $.580^{* *}$ & $.483^{* *}$ & 1.000 & $\begin{array}{c}\text { Descriptive } \\
\text { Statistics }\end{array}$ \\
\hline $.609^{* *}$ & $.227^{* *}$ & $.506^{* *}$ & $.534^{* *}$ & $.495^{* *}$ & 1.000 & & $\begin{array}{c}\text { Statistical } \\
\text { Hypotheses }\end{array}$ \\
\hline $.599^{* *}$ & $.325^{* *}$ & $.528^{* *}$ & $.286^{* *}$ & 1.000 & & & $\begin{array}{c}\text { Interpretation of } \\
\text { Statistical } \\
\text { Significance }\end{array}$ \\
\hline $.685^{* *}$ & $.272^{* *}$ & $.528^{* *}$ & 1.000 & & & & $\begin{array}{c}\text { Parametric } \\
\text { statistical } \\
\text { methods }\end{array}$ \\
\hline $.599^{* *}$ & $.325^{* *}$ & 1.000 & & & & & $\begin{array}{c}\text { Non-Parametric } \\
\text { statistical } \\
\text { methods }\end{array}$ \\
\hline 1.000 & 1.000 & & & & & & $\begin{array}{c}\text { Use of } \\
\text { Statistical } \\
\text { Package of } \\
\text { SPSS } \\
\text { Total Score }\end{array}$ \\
\hline
\end{tabular}

$* *$ Statically significant at $\alpha=0.01$.

Table 4 illustrates the relationship between academic skills in the peer assessment model, where it shows signs of statistical significance of at $(\alpha=0.01)$ between all dimensions (descriptive statistics, statistical hypotheses, interpretation of statistical significance, parametric statistical methods, non-parametric statistical methods, use of the statistical package of SPSS, as well as between all dimensions with a total score at $(\alpha=0.01)$. These results reflect that peer assessment is a suitable standard to be used as an assessment tool. On the other hand, these results are matched with each of Strijbos and Sluijsmans (2010) and Boud and Falchikov's (2007) studies which argue that peer assessment is a tool with which students evaluate the performance of their peers. Additionally, the University of Sussex's (2015) study confirms that students can actively participate in defining their peer assessment criteria's methods and quantity.

Hypothesis \#2:There are no statistically significant differences between peer assessment and teacher assessment in each of the organizational and academic skills.

A significant difference was found between the average ratings of students and teacher assessments in each of the academic and organizational skills dimensions. Table 5 presents the averages and Standard Deviations of peer and teacher assessments for organizational and academic skills dimensions. On the other hand T. Test for Peer and Teacher Assessments for Organizational and Academic Skills Dimensions were calculated in order to prove or refuse this hypothesis. Table 6 presents T. Test for Peer and Teacher Assessments for Organizational and Academic Skills Dimensions (Paired Samples Test). 
Table 5. Averages and standard deviations of peer and teacher assessments for organizational and academic skills dimensions

\begin{tabular}{lccccc}
\hline Std. Error Mean & Std. Deviation & N & Mean & & \\
\hline .03551 & .25108 & 50 & 3.5197 & $\begin{array}{c}\text { Organizational peer } \\
\text { assessment } \\
\text { Organizational Teacher } \\
\text { Assessment } \\
\text { Academic Peer } \\
\text { Assessment }\end{array}$ & Pair 1 \\
.0354 & .2504 & 50 & 3.517 & Pair 2 \\
.0509 & .34739 & 50 & 3.3740 & $\begin{array}{c}\text { Academic Teacher } \\
\text { Assessment }\end{array}$ & \\
\hline
\end{tabular}

Table 6. T. Test for peer and teacher assessments for organizational and academic skills dimensions paired samples test

\begin{tabular}{|c|c|c|c|c|c|c|}
\hline \multirow[b]{2}{*}{ Sig. (2-tailed) } & \multirow[b]{2}{*}{ df } & \multirow[b]{2}{*}{$\mathbf{t}$} & \multicolumn{3}{|c|}{ Paired Differences } & \\
\hline & & & $\begin{array}{c}\text { Std. Error } \\
\text { Mean }\end{array}$ & $\begin{array}{c}\text { Std. } \\
\text { Deviation }\end{array}$ & Mean & \\
\hline .182 & 49 & 1.353 & .00222 & .01568 & .00300 & $\begin{array}{c}\text { Organizational Teacher } \\
\text { Assessment-Peer Assessment }\end{array}$ \\
\hline .084 & 49 & -1.765 & .01039 & .07346 & -.01833 & $\begin{array}{c}\text { Academic Teacher } \\
\text { Assessment-Peer Assessment }\end{array}$ \\
\hline
\end{tabular}

Tables $5 \& 6$ show T. test results for two related samples accepting the null hypothesis that there are no statistically significant differences between the peer assessment mean and the teacher assessment mean for organizational and academic skills dimensions. This result was consistent with Falchikov and Goldfinch's (2000) study which revealed using a meta-analysis that there is concordance between peer and teacher assessments, as well as Sahin's (2008) study which confirmed that peer assessments is constant with teacher assessments.

Hypothesis\#3: There is a statistical significant relationship between peer assessments of academic skills and teacher assessments. To check this hypothesis, Pearson correlation coefficient was calculated among peer assessments of academic skills and teacher assessment. Table 7 presents the results of Pearson correlation coefficient among peer assessments of academic skills and teacher assessments.

Table 7. Pearson correlation coefficient among peer assessment of academic skills and teacher assessment

\begin{tabular}{|c|c|c|c|}
\hline \multicolumn{4}{|c|}{ Correlations } \\
\hline Teacher assessment & Peer assessment & & \\
\hline $.507^{* *}$ & 1 & Pearson Correlation & \\
\hline .000 & & Sig. (2-tailed) & Peer assessment \\
\hline 50 & 50 & $\mathrm{~N}$ & \\
\hline 1 & $.507^{* *}$ & Pearson Correlation & \\
\hline & .000 & Sig. (2-tailed) & leacher \\
\hline 50 & 50 & $\mathrm{~N}$ & assessment \\
\hline
\end{tabular}

$* *$ Correlation is significant at $\alpha=0.01$ (2-tailed).

Table 7 shows the relationship between peer assessment and teacher assessment of academic skills. It shows statistically significant relationships at $\alpha=0.01$, which indicates the positive relationship between peer and teacher assessments. This is confirmed by both Sahin (2008) and Falchikov and Goldfinch's (2000) studies that confirmed peer assessments consist with teacher assessment at a statistically significant level, and that grades received by students from teachers are met with consistent grades from their peers.

To sum up; the results of this study regarding peer assessment as a standard for evaluation have a similarity with the results of many studies that emphasized the importance of the students' participation in the process of evaluation (Boud \& Falchikov, 2007; Spiller, 2009). Landry et al. (2014) and Lew et al. (2008) studies also confirmed the importance of using peer assessment as a tool for student-based learning, and that students agree 
that peer assessment gives them the opportunity to learn and evaluate their peers. This study, in addition to Tan and Keat's (2005) study emphasized involving students in formulating evaluation criteria where they can rely on peer assessment as a valid tool for assessment in problem-based learning. The results also show a correlation between peer assessment and teacher assessment, which is consistent with the findings of Falchikov and Goldfinch (2000) and Sahin's (2008) studies, considering peer assessment a criterion that can be used in student assessment in addition to teacher assessment.

\section{Conclusion}

Peer assessment is an important part of the move towards more forms of participatory learning. There is a need to apply it in our schools and universities since it is more adaptable to modern developments in the assessment of learning outcomes. We, as educators, are required to encourage teachers to shed light on peer assessment as a strategy to assess students and on the need for more applications and experimental research in the future.

\section{Recommendations}

In light of the results of the current study, the researcher recommends that peer assessment can be used as an alternative to conventional methods in the evaluation of the learning process, which helps in the measurement of students' achievement from their peers' points of view. On the other hand, the researcher encourages other researchers to conduct comparative studies between self-assessment and peer assessment. Also, she inspires students to participate in preparing peer assessment models. Consequently, the students will be responsible about their own learning to achieve a personal and professional development.

\section{References}

Boud, D., \& Falchikov, N. (Eds.). (2007). Rethinking Assessment in Higher Education: Learning for the Longer Term. London: Routledge.

Chang, C., Tseng, K., Chou, P., \& Chen, Y. (2011). Reliability and validity of Web-based portfolio peer assessment: A case study for a senior high school's students taking computer course. Computers \& Education, 57(1), 1306-1316. https://doi.org/10.1016/j.compedu.2011.01.014

Cho, K., \& MacArthur, C. (2010). Student revision with peer and expert reviewing. Learning and Instruction, 20(4), 328-338. https://doi.org/10.1016/j.learninstruc.2009.08.006

Cho, K., Schunn, C., \& Wilson, R. (2006). Validity and reliability of scaffolded peer assessment of writing from instructor and student perspectives. Journal of Educational Psychology, 98(4), 891-901. https://doi.org/10.1037/0022-0663.98.4.891

Deakin-Crick, R., Sebba, J., Harlen, W., Guoxing, Y., \& Lawson, H. (2005). Systematic review of research evidence of the impact on students of self- and peer-assessment. Protocol. In: Research Evidence in Education Library. London: EPPI-Centre, Social Science Research Unit, Institute of Education, University of London.

Elander, J. (2004). Student assessment from a psychological perspective. Psychology Learning \& Teaching, 3(2), 114-121. https://doi.org/10.2304/plat.2003.3.2.114

Falchikov, N., \& Goldfinch, J. (2000). Student peer assessment in higher education: a meta-analysis comparing peer and teacher marks. Review of Educational Research, 70(3), 287-322. https://doi.org/10.3102/00346543070003287

Ghorpade, J., \& Lackritz, J. (2001). Peer evaluation in the classroom: A check for sex and race/ethnicity effects. Journal of Education for Business, 76(5), 274-281. https://doi.org/10.1080/08832320109599648

Gielen, M., \& De Wever, B. (2015). Structuring peer assessment: Comparing the impact of the degree of structure on peer feedback content. Computers in Human Behavior, 52, 315-325. https://doi.org/10.1016/j.chb.2015.06.019

Gielen, S., Dochy, F., Onghena, P., Struyven, K., \& Smeets, S. (2011). Goals of peer assessment and their associated quality concepts. Studies in Higher Education, 36(6), 719-735. https://doi.org/10.1080/03075071003759037

Kearney, S., Perkins, T., \& Kennedy-Clark, S. (2015). Using self-and peer-assessments for summative purposes: analysing the relative validity of the AASL (Authentic Assessment for Sustainable Learning) model. Assessment \& Evaluation in Higher Education, 1-14.

Kollar, I., \& Fischer, F. (2010). Peer assessment as collaborative learning: A cognitive perspective. Learning and Instruction, 20(4), 344-348. https://doi.org/10.1016/j.learninstruc.2009.08.005 
Landry, A., Jacobs, S., \& Newton, G. (2014). Effective Use of Peer Assessment in a Graduate Level Writing Assignment: A Case Study. International Journal of Higher Education, 4(1), 38-51. https://doi.org/10.5430/ijhe.v4n1p38

Lew, M., Alwis,W., \& Schmidt, H. (2008). Self and Peer Assessment as an Assessment Tool in Problem-based Learning. iaea 2008.

Liu, X., \& Li, L. (2014). Assessment training effects on student assessment skills and task performance in a technology-facilitated peer assessment. Assessment \& Evaluation in Higher Education, 39(3), 275-292. https://doi.org/10.1080/02602938.2013.823540

Lladó, A., Soley, L., Sansbelló, R., Pujolras, G., Planella, J., Roura-Pascual, N., \& Moreno, L. (2014). Student perceptions of peer assessment: An interdisciplinary study. Assessment \& Evaluation in Higher Education, 39(5), 592-610. https://doi.org/10.1080/02602938.2013.860077

Lutze-Mann, L. (2015). Peer Assessment of Assignment Drafts: About Peer Assessment. Assessment Toolkit, Student Peer Assessment. Retrieved from https://teaching.unsw.edu.au/peer-assessment

Marsh, H. W., Jayasinghe, U. W., \& Bond, N. W. (2008). Improving the peer-review process for grant applications: reliability, validity, bias, and generalizability. American Psychologist, 63(3), 160-168. https://doi.org/10.1037/0003-066X.63.3.160

Papinczak, T., Young, L., Groves, M., \& Haynes, M. (2007). An analysis of peer, self, and tutor assessment in problem-based learning tutorials. Med Teach, 29(5), 122-132. https://doi.org/10.1080/01421590701294323

Race, P. (2001). A Briefing on Self, Peer and Group Assessment. LTSN Generic Centre Assessment Series No. 9.

Rimer, S. (2007). Harvard task force calls for new focus on teaching and not just research. The New York Times. Retrieved from http://www.nytimes.com/2007/05/10/education/10harvard.html

Rogers, R., \& Threatt, D. (2000). Peer assistance and peer review. Thrust for Educational Leadership, 29(3), $14-16$.

Ross, J. (2006). The Reliability, Validity, and Utility of Self-Assessment, Practical Assessment Research \& Evaluation, 11(10). 1-13.

Rust, C., Price, M., \& O’Donovan, B. (2003). Improving students' learning by developing their understanding of assessment criteria and processes. Assessment \& Evaluation in Higher Education, 28(2), 147-164. https://doi.org/10.1080/02602930301671

Sahin, S. (2008). An application of peer assessment in higher education. The Turkish Online Journal of Educational Technology, 7(2), 5-10.

Sivan, A. (2002). Implementing peer assessment to enhance teaching and learning. New Horizons, 1(2), 10-11.

Sluijsmans, D., Dochy, F., \& Moerkerke, G. (1998). The use of self-, peer-and co-assessment in higher education. Open University of the Netherlands, Heerlen.

Spiller, D. (2009). Assessment Matters: Self-Assessment and Peer Assessment. Teaching Development, The University of Waikato. Retrieved from http://www.waikato.ac.nz/tdu/pdf/booklets/8_SelfPeerAssessment. pdf

Strijbos, J., \& Sluijsmans, D. (2010). Unravelling peer assessment: Methodological, functional, and conceptual developments. Learning and Instruction, 20(4), 265-269. https://doi.org/10.1016/j.learninstruc.2009.08.002

Tan, K., \& Keat, L. (2005). Self and Peer Assessment as an Assessment Tool in Problem-based Learning. Problem-Based Learning: New Directions and Approaches, 162-175.

Thomas, G., Martin, D., \& Pleasants, K. (2011). Using self-and peer-assessment to enhance students' future-learning in higher education. Journal of University Teaching and Learning Practice, 8(1), 5.

UK University of Sussex. (2015). Teaching and Learning Development Unit: Peer Assessment and Feedback. Retrieved from http://www.sussex.ac.uk/tldu/ideas/assessment/peer

Wesson, R. (2014). Peer and Self Assessment. Deakin Learning Futures, Deakin University. Retrieved from http://www.deakin.edu.au/_data/assets/pdf_file/0020/53462/peer-and-self-assessment.pdf 


\section{Appendix}

\section{Peer Assessment Template}

Name: Year: Major: $\quad$ Cumulative grade average:

Dear student:

You are required to evaluate your fellow students in each dimension during your work in collaborative groups for Statistical Psychology course. Be objective in your evaluation. The average scores of all group members will be calculated from each evaluation sheet.

First: the organizational skills of the cooperative group

\section{Leadership}

\begin{tabular}{|c|c|c|c|c|}
\hline Members & $\begin{array}{c}1 \\
\text { Does not take any } \\
\text { responsibilities in } \\
\text { leading, } \\
\text { unproductive }\end{array}$ & $\begin{array}{c}\text { Does not share } \\
\text { the leadership role } \\
\text { with members }\end{array}$ & $\begin{array}{c}\text { Usually leads } \\
\text { appropriately, } \\
\text { and sometimes } \\
\text { shares the } \\
\text { leadership role }\end{array}$ & $\begin{array}{c}4 \\
\text { Leading appropriately, } \\
\text { helping members, } \\
\text { encouraging participation, } \\
\text { suggesting solutions for } \\
\text { problems, and sharing the } \\
\text { leadership role. }\end{array}$ \\
\hline & & & & \\
\hline & & & & \\
\hline
\end{tabular}

\section{Listening}

\begin{tabular}{|c|c|c|c|c|}
\hline Members & $\begin{array}{c}1 \\
\text { Never listens to } \\
\text { others }\end{array}$ & $\begin{array}{c}2 \\
\text { Often listens to } \\
\text { others' ideas }\end{array}$ & $\begin{array}{c}\text { Usually listens to other } \\
\text { members' ideas }\end{array}$ & $\begin{array}{c}\text { Listens very } \\
\text { carefully for } \\
\text { other members' } \\
\text { ideas }\end{array}$ \\
\hline & & & & \\
\hline & & & & \\
\hline & & & & \\
\hline
\end{tabular}




\section{Feedback}

\begin{tabular}{|c|c|c|c|c|}
\hline Members & $\begin{array}{c}1 \\
\text { Does not give any } \\
\text { comments for } \\
\text { others' reactions, or } \\
\text { helpful information }\end{array}$ & $\begin{array}{c}\text { Often gives } \\
\text { comments for } \\
\text { others' reactions, } \\
\text { but may be } \\
\text { inappropriate or } \\
\text { unhelpful }\end{array}$ & $\begin{array}{c}\text { Appropriately comments } \\
\text { on others' reactions }\end{array}$ & $\begin{array}{c}\mathbf{4} \\
\text { Gives comments } \\
\text { for group } \\
\text { members on } \\
\text { their } \\
\text { performance } \\
\text { for the needed } \\
\text { work and } \\
\text { presents details } \\
\text { about others' } \\
\text { reactions } \\
\text { appropriately }\end{array}$ \\
\hline & & & & \\
\hline & & & & \\
\hline & & & & \\
\hline
\end{tabular}

\section{Cooperation}

\begin{tabular}{|c|c|c|c|c|}
\hline Members & $\begin{array}{c}\text { 1 } \\
\text { Treats others } \\
\text { disrespectfully and } \\
\text { does not engage in } \\
\text { the work load }\end{array}$ & $\begin{array}{c}2 \\
\text { Rarely treats others } \\
\text { disrespectfully or } \\
\text { rarely engages in } \\
\text { the work load }\end{array}$ & $\begin{array}{c}\text { Treats others } \\
\text { respectfully and } \\
\text { sometimes engages } \\
\text { the work load }\end{array}$ & $\begin{array}{c}\text { Theats others } \\
\text { respectfully } \\
\text { and engages in the } \\
\text { work load a lot }\end{array}$ \\
\hline & & & & \\
\hline & & & & \\
\hline
\end{tabular}

\section{Time management}

\begin{tabular}{|l|c|c|c|c|}
\hline Members & $\begin{array}{c}1 \\
\text { Does not finish } \\
\text { given tasks on } \\
\text { time and may lose } \\
\text { work at the last } \\
\text { moment }\end{array}$ & $\begin{array}{c}\text { Often does not } \\
\text { finish given taks } \\
\text { on time }\end{array}$ & $\begin{array}{c}\text { Usually finishes } \\
\text { tasks on } \\
\text { deadlines }\end{array}$ \\
& & & $\begin{array}{c}\text { Quick in finishing } \\
\text { given tasks before } \\
\text { deadlines }\end{array}$ \\
\hline & & & & \\
\hline & & & & \\
\hline & & & & \\
\hline
\end{tabular}

Second: Academic skills of the cooperative group 
1. Descriptive statistics skills

\begin{tabular}{|c|c|c|c|c|}
\hline Member & $\begin{array}{c}1 \\
\text { Is not proficient in } \\
\text { any central } \\
\text { tendency and } \\
\text { dispersion measures }\end{array}$ & $\begin{array}{c}\text { Proficient in some } \\
\text { central tendency and } \\
\text { dispersion measures }\end{array}$ & $\begin{array}{c}\text { 3 } \\
\text { Proficient in many } \\
\text { central tendency } \\
\text { and dispersion } \\
\text { measures }\end{array}$ & $\begin{array}{c}\text { Proficient in all } \\
\text { applications of } \\
\text { central tendency } \\
\text { and dispersion } \\
\text { measures }\end{array}$ \\
\hline & & & & \\
\hline & & & & \\
\hline & & & & \\
\hline
\end{tabular}

\section{Statistical Hypotheses}

\begin{tabular}{|c|c|c|c|c|}
\hline Members & $\begin{array}{c}1 \\
\text { Is not proficient } \\
\text { on } \\
\text { any skills of } \\
\text { formulation and } \\
\text { testing of statistical } \\
\text { hypotheses }\end{array}$ & $\begin{array}{c}2 \\
\text { Proficient in some } \\
\text { skills of } \\
\text { formulation and } \\
\text { testing of statistical } \\
\text { hypotheses }\end{array}$ & $\begin{array}{c}3 \\
\text { Proficient in many } \\
\text { skills of } \\
\text { formulation and } \\
\text { testing of statistical } \\
\text { hypotheses }\end{array}$ & $\begin{array}{c}\text { Proficient in all } \\
\text { skills of formulation } \\
\text { and testing of } \\
\text { statistical } \\
\text { hypotheses }\end{array}$ \\
\hline & & & & \\
\hline & & & & \\
\hline & & & & \\
\hline
\end{tabular}

3. Interpretation of statistical significance

\begin{tabular}{|l|c|c|c|c|}
\hline Members & $\begin{array}{c}1 \\
\text { Cannot interpret } \\
\text { statistical } \\
\text { significance of } \\
\text { statistical tests at } \\
\text { all }\end{array}$ & $\begin{array}{c}\text { Hardly defines and } \\
\text { interprets } \\
\text { statistical } \\
\text { significance of } \\
\text { statistical tests }\end{array}$ & $\begin{array}{c}\text { 3 } \\
\text { Defines and } \\
\text { interprets many } \\
\text { statistical } \\
\text { significances of } \\
\text { statistical tests }\end{array}$ & $\begin{array}{c}\text { Strongly defines } \\
\text { and interprets } \\
\text { statistical } \\
\text { significance of } \\
\text { statistical tests }\end{array}$ \\
\hline & & & & \\
\hline & & & & \\
\hline & & & & \\
\hline
\end{tabular}


4. Parametric statistical methods

\begin{tabular}{|c|c|c|c|c|}
\hline Members & $\begin{array}{c}1 \\
\text { Not proficient in } \\
\text { applying any } \\
\text { parametric } \\
\text { statistical methods } \\
\text { at all }\end{array}$ & $\begin{array}{c}\text { 2 } \\
\text { Proficient in little } \\
\text { application skills } \\
\text { of parametric } \\
\text { statistical methods }\end{array}$ & $\begin{array}{c}3 \\
\text { Proficient in many } \\
\text { skills of } \\
\text { application of } \\
\text { parametric } \\
\text { statistical methods }\end{array}$ & $\begin{array}{c}\text { Strongly proficient } \\
\text { in applying } \\
\text { parametric } \\
\text { statistical methods }\end{array}$ \\
\hline & & & & \\
\hline & & & & \\
\hline & & & & \\
\hline
\end{tabular}

5. Non-Parametric statistical methods

\begin{tabular}{|c|c|c|c|c|}
\hline Members & $\begin{array}{c}1 \\
\text { Not proficient in } \\
\text { applying any non } \\
\text { parametric } \\
\text { statistical methods } \\
\text { at all }\end{array}$ & $\begin{array}{c}\text { 2 } \\
\text { Proficient in little } \\
\text { application skills } \\
\text { of non parametric } \\
\text { statistical methods }\end{array}$ & $\begin{array}{c}3 \\
\text { Proficient in many } \\
\text { application skills } \\
\text { of non parametric } \\
\text { statistical methods }\end{array}$ & $\begin{array}{c}\text { Strongly proficient } \\
\text { in applying non } \\
\text { parametric } \\
\text { statistical methods }\end{array}$ \\
\hline & & & & \\
\hline & & & & \\
\hline & & & & \\
\hline
\end{tabular}

6. Use of statistical analysis package of SPSS

\begin{tabular}{|c|c|c|c|c|}
\hline Members & $\begin{array}{c}1 \\
\text { Not proficient in } \\
\text { performing } \\
\text { statistical analyses } \\
\text { using SPSS at all }\end{array}$ & $\begin{array}{c}2 \\
\text { Proficient in little } \\
\text { skills of } \\
\text { performing } \\
\text { statistical analyses } \\
\text { using SPSS }\end{array}$ & $\begin{array}{c}3 \\
\text { Proficient in many } \\
\text { skills of } \\
\text { performing } \\
\text { statistical analyses } \\
\text { using SPSS }\end{array}$ & $\begin{array}{c}4 \\
\text { Strongly } \\
\text { proficient in } \\
\text { performing } \\
\text { statistical analyses } \\
\text { using SPSS }\end{array}$ \\
\hline & & & & \\
\hline & & & & \\
\hline & & & & \\
\hline
\end{tabular}

\section{Copyrights}

Copyright for this article is retained by the author(s), with first publication rights granted to the journal.

This is an open-access article distributed under the terms and conditions of the Creative Commons Attribution license (http://creativecommons.org/licenses/by/4.0/). 